\title{
Article \\ Elevational Patterns of Blowfly Parasitism in Two Hole Nesting Avian Species
}

\author{
Gregorio Moreno-Rueda
}

Citation: Moreno-Rueda, G Elevational Patterns of Blowfly Parasitism in Two Hole Nesting Avian Species. Diversity 2021, 13, 591. https://doi.org/10.3390/d13110591

Academic Editor: Gary Voelker

Received: 12 October 2021

Accepted: 17 November 2021

Published: 18 November 2021

Publisher's Note: MDPI stays neutral with regard to jurisdictional claims in published maps and institutional affiliations.

Copyright: (C) 2021 by the author. Licensee MDPI, Basel, Switzerland. This article is an open access article distributed under the terms and conditions of the Creative Commons Attribution (CC BY) license (https:/ / creativecommons.org/licenses/by/ $4.0 /)$.
Departamento de Zoología, Facultad de Ciencias, Universidad de Granada, 18071 Granada, Spain; gmr@ugr.es

\begin{abstract}
Climate change is predicted to cause shifts in parasite distributions, leading to encounters with new hosts. Mountains offer a natural experimental background to study how parasite distributions vary across climatic gradients. Parasite abundance is generally assumed to decrease with ascending elevation, as colder climates may preclude several parasites to complete their life cycles. The present study analyses the elevational variation in the prevalence and intensity of the blowfly Protocalliphora azurea found in the nests of two hosts-the coal tit (Periparus ater) and great tit (Parus major) —in Sierra Nevada (SE Spain). Protocalliphora azurea adults are free-living flies, while their larvae are nest-dwelling parasites that feed on nestling blood. In contrast to initial predictions, P. azurea larvae were less prevalent at lower elevations. In Mediterranean environments, the colder and damper climate of medium and high elevations might favour this parasite. Alternatively, greater anthropogenic perturbation in lowland environments may have a negative impact on the parasite. The findings also show that the two host species had similar parasite loads. As coal tits are half the size of great tits, this suggests that the coal tits were more severely parasitised. In conclusion, the generalised assumption that parasite abundance decreases with elevation does not hold true for the present case and elevational parasite patterns probably depend on specific host-parasite systems and climatic conditions in the mountains.
\end{abstract}

Keywords: elevational patterns; Protocalliphora azurea; Parus major; Periparus ater; Mediterranean environments

\section{Introduction}

Parasites take their resources from hosts, which reduces host fitness, so they have important implications in host ecology and evolution [1]. Hence, parasite ecology is a central topic in evolutionary ecology. One of the most studied host-parasite systems is that formed by nestling birds and their parasites. Bird nests often harbour a variety of arthropod parasites which feed on the nestlings' blood, frequently with detrimental effects on their health, body condition, and survival [2-6] or on the parent future fitness if they respond to nest parasitism through increased feeding rate [7].

Several factors influence the parasite species that can be found in a nest and their abundance. For example, ambient temperature and humidity and food availability all affect the dispersal phase of nest parasites [8,9]. Abiotic conditions, such as temperature and humidity in the nest, also impact parasite colonisation and within-nest population size [10-12]. Nest-dwelling parasites may also be affected by other competitors and predators dwelling in the nest $[13,14]$. Moreover, host characteristics may affect parasite presence and abundance. Hosts display several antiparasitic strategies including, in the case of nest ectoparasites, nest sanitation by adults and scratching by nestlings $[15,16]$. The strength of nestlings' immune systems also plays an important role in defending them against nest-dwelling ectoparasites [17]. Ectoparasites provoke tissue and cell injuries in birds, which stimulate an immune response including inflammation and the activation of an array of leucocytes and immunoglobulins. This, in turn, has a negative impact on the parasite by physically preventing its access to the chick's blood as well as damaging 
parasite tissues, thus reducing the amount of blood meal consumed by the ectoparasite and consequently its fecundity and survival [18]. Indeed, a strong nestling immune system is known to reduce the success of nest-dwelling ectoparasites [19-23]. Several of these factors that affect parasite success (and hence their presence or absence) vary geographically, including the host immune response [24], as it is influenced by food availability and temperature [25-28]. Therefore, nest parasite prevalence and intensity may vary according to geographical factors and the host species. However, we only have very limited knowledge of the geographical variations in bird nest parasites.

Climate change is expected to produce shifts in parasite distributions, particularly toward more northern latitudes (in the Northern Hemisphere) and higher elevations [29]. In fact, parasite abundance in Europe has increased in recent years [30]. These changes in distribution may lead to new host-parasite encounters, forcing host populations to deal with parasites with which they have not coevolved. It is hard to predict how these new host-parasite relationships will affect wildlife, but they could eventually lead to local extinctions of host populations [31].

Accordingly, elevational gradients in mountainous areas constitute a natural setting to study the geographical distribution of parasites along climatic clines. It is generally accepted that parasite abundance decreases with elevation [32]. This is a reasonable assumption, given that higher elevations mean ectoparasites have to deal with lower temperatures, less daily and annual time to complete their life cycles, and long periods of host hibernation, which probably increase ectoparasite mortality. However, there is not a lot of evidence available to support this assumption. The prevalence of the parasitic mite Riccardoella limacum on the land snail Arianta arbustorum is zero at high elevations [33]. Similarly, the abundance of feather mites (ectosymbionts whose parasitic role is still being debated) on birds diminishes with elevation [34]. However, the prevalence of haematophagous Acari on lizards has been reported to decrease [35,36], increase [37,38] or even remain constant [39] with increasing elevation, depending on the host-parasite system studied. Similar hostparasite systems involving nest-dwelling parasites and nestling birds also provide mixed results. Parasitism intensity by Philornis downsi (Diptera: Muscidae) larvae in Darwin's finches nests in the Galapagos Islands was found to increase with elevation [40,41], but, by contrast, the parasitism intensity of Philornis carinatus in nests of house wrens (Troglodytes aedon) in Costa Rica decreased with elevation [42].

The present study analyses the elevational variation in parasite prevalence and intensity of the blowfly Protocalliphora azurea among coal tit (Periparus ater) and great tit (Parus major; Figure 1) nests located in pine forests of the Sierra Nevada mountain range (SE Spain). Protocalliphora azurea adults are free-living blowflies that lay their eggs in bird nests, parasitising a huge variety of bird species. Blowfly larvae shelter beneath nesting material and feed intermittently on nestlings' blood, typically pupating once fledglings have left the nest [8]. Parasitism by P. azurea negatively affects nestling fitness, frequently reducing the haematocrit, body mass and tarsus length [43-48], increasing nestling stress [49] and even reducing nestling survival [50,51], recruitment [6] and future reproduction [52] Despite the species' widespread distribution and impact on birds, we know very little about the geographic variation in P. azurea parasitism (but see [53]), although among-habitat variation has been reported [49,54]. Adult blowflies overwinter out of the nest, and their activity is temperature-dependent; they are inactive at temperatures of less than $15^{\circ} \mathrm{C}$. Moreover, shorter pupation times occur at higher temperatures $[8,55,56]$. Hence, although nest microclimate is not necessarily subject to significant elevational variation when tits are inside the nest, the ambient temperature outside the nest during the adult phase and the temperature inside the nest during pupation probably decrease with elevation, negatively impacting on blowfly fitness. It is therefore predicted that blowfly parasitism (prevalence and/or intensity of infestation) will diminish with increasing elevation. Consequently, the goal of the present study is to test the hypothesis that parasitism decreases with elevation, using as a model system blowflies parasitising tits in a Mediterranean mountain. 

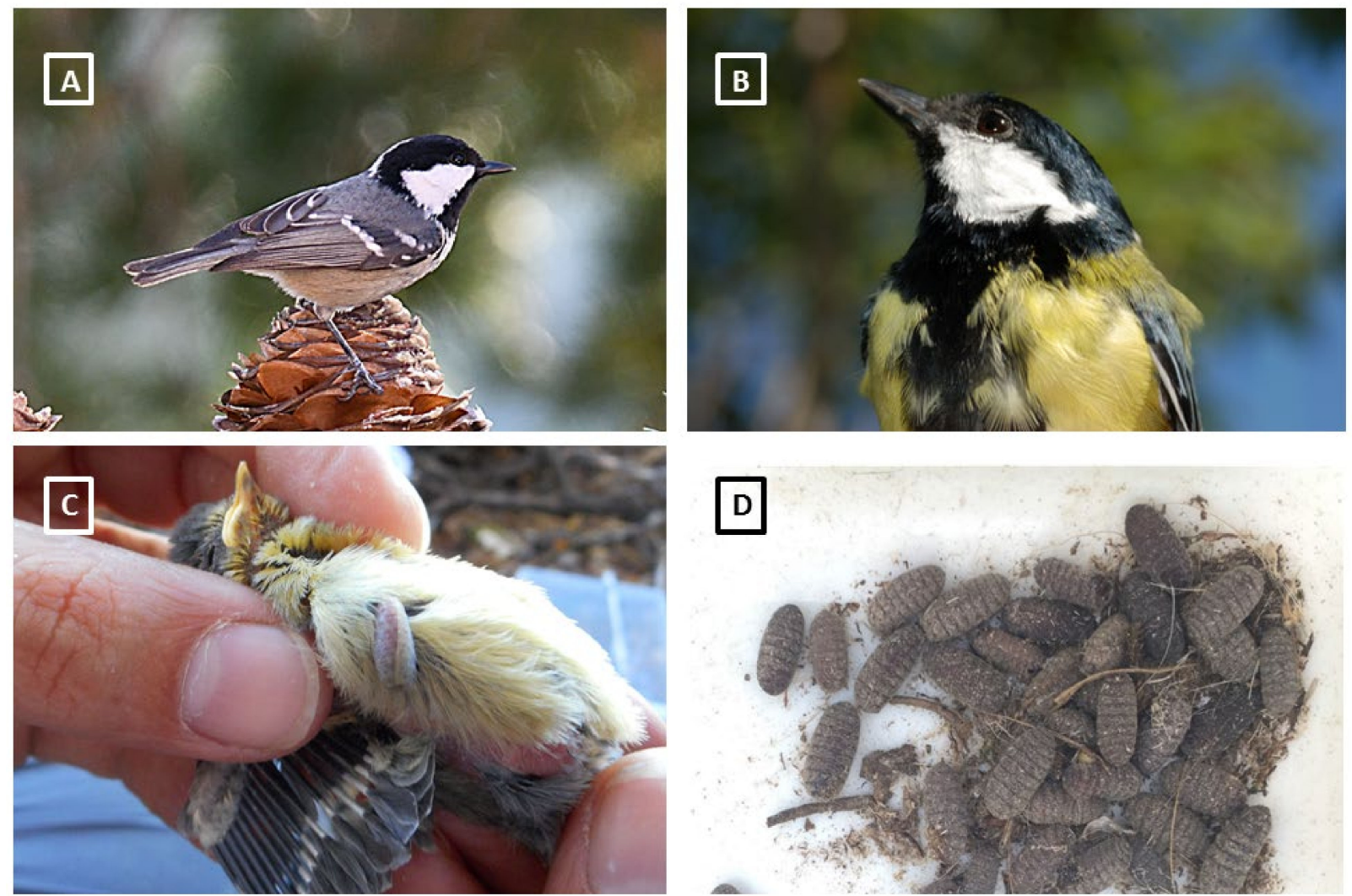

Figure 1. Host species: (A) coal tit, (B) great tit. A blowfly larva parasitising a blue tit (Cyanistes caeruleus) nestling (C). Several blowfly puparia collected from a nest (D). Photos A and B courtesy of Mar Comas.

\section{Materials and Methods}

The coal tit is a $10 \mathrm{~g}$ Palearctic passerine bird typically associated with pine forests [57]. The great tit is a $19 \mathrm{~g}$ Palearctic passerine forest bird associated with a wide range of forests [58]. The two species are distributed as resident across a broad elevational range in the southern Iberian Peninsula, from sea level to $2400 \mathrm{~m}[57,59]$. Both species nest in cavities (usually tree cavities), so they readily use nest boxes for breeding [60]. Exploiting the use of nest boxes by these birds, in the winter of 2016, I placed 180 clean ICONA C model nest boxes (base: $200 \mathrm{~cm}^{2}$; height: $20 \mathrm{~cm}$; hole diameter: $3 \mathrm{~cm}$; material: wood with external plastic paint coating; more details in [61]) in three pine forests (60 nest-boxes per locality) situated across an elevational gradient in Sierra Nevada (south-eastern Spain). The three pine forest localities having been used since 2010 and were Albergue de Lecrín $\left(36^{\circ} 56^{\prime} \mathrm{N}, 3^{\circ} 30^{\prime} \mathrm{W} ; 1200 \mathrm{~m}\right.$ asl), Puentepalo $\left(36^{\circ} 58^{\prime} \mathrm{N}, 3^{\circ} 24^{\prime} \mathrm{W} ; 1800 \mathrm{~m}\right.$ asl) and Hoya del Portillo $\left(36^{\circ} 58^{\prime} \mathrm{N}, 3^{\circ} 19^{\prime} \mathrm{W} ; 2200 \mathrm{~m}\right.$ asl). The pine forests consisted of reforestations, mainly of Pinus sylvestris, with little understory and were chosen to provide the most similar habitat possible along the elevational gradient. Nest boxes were hung 4-5 metres above the ground from a pine tree branch using a metal hook. Nest boxes were visited regularly (at least once per week) to identify the species breeding in each box and record nest box content (empty nest, eggs, nestlings, fledglings, etc.). The study only contemplated successful breeding attempts, that is, those in which at least one nestling fledged. The study includes a total of 37 coal tit nests (7 in Albergue de Lecrín, 14 in Puentepalo and 16 in Hoya del Portillo) and 30 great tit nests (21 in Albergue de Lecrín, 6 in Puentepalo, and 3 in Hoya del Portillo). Once fledglings left the nest, nest material was carefully revised and the presence and number of blowfly puparia per nest was recorded.

I analysed whether blowfly presence or absence in each nest varied with elevation using a Generalised Linear Model with a binomial distribution (parasitised or not parasitised) linked to a logit function. The predictive variables were locality, host species (coal 
tit or great tit) and their interaction. It was also analysed whether parasitism intensity (i.e., number of blowflies per parasitised nest, according to [62]) varied with elevation. In this case, only parasitised nests were used. Given the low sample size after splitting species by elevation, and as intensity did not differ between species (see Results), the infestation intensities for the two species were pooled to ascertain the elevational variation. The variation in intensity (log-transformed) was analysed with a linear model (ANOVA) using locality as the predictor. In addition, the elevational variation in intensity (with raw data) was analysed with a Generalised Linear Model. Student's $t$-test was used to compare brood size and blowfly intensity between species as well as brood size between parasitised and non-parasitised nests. The normality and homoscedasticity of the model residuals were verified graphically and with the Shapiro-Wilk (normality) and Levene (homoscedasticity) tests [63]. The variable intensity of infestation was log-transformed to guarantee the normality of the data. Mean values (untransformed data) of blowfly intensity are given with the standard error. Raw data are available in Appendix A. Statistical analyses were carried out with Statistica 8.0.

\section{Results}

Brood size did not differ between the two species (coal tit: $6.13 \pm 0.25$, range $=2-8$, $n=37$; great tit: $5.73 \pm 0.33$ nestlings, range $=1-9, n=30 ; t_{65}=0.97, p=0.34$ ) nor between parasitised (5.88 \pm 0.30 nestlings, $n=38)$ and unparasitised nests ( $6.00 \pm 0.28$ nestlings, $\left.n=29 ; t_{65}=0.30, p=0.77\right)$. For both coal and great tits, the percentage of nests infested with blowflies was the lowest (14-33\%) at Albergue de Lecrín, the locality at the lowest elevation (1200 m), and higher at both Puentepalo (1800 m) and Hoya del Portillo (2200 m) (50-86\%; Figure 2). The Generalised Linear Model with binomial distribution showed that the prevalence of blowflies significantly varied among localities but did not differ between tit species (Table 1). The species*locality interaction was not statistically significant (Table 1). Great tit nests infested with blowflies had an average of $14.25 \pm 3.27$ pupae (range $=1-37, n=12$ nests), while coal tit nests had an average of $12.88 \pm 2.68$ pupae (range $=1-53, n=26$ nests). Infestation intensity did not differ between species $\left(t_{36}=0.30\right.$, $p=0.77)$. Intensity did not vary with elevation $\left(F_{2,35}=0.08, p=0.92\right.$; pupae per nest: Albergue de Lecrín: $13.62 \pm 3.62, n=8$; Puentepalo: $13.13 \pm 3.76, n=15$; Hoya del Portillo: $13.33 \pm 3.38, n=15$ ). A Generalised Linear Model provided similar results (Wald statistic: $0.095, p=0.95)$.

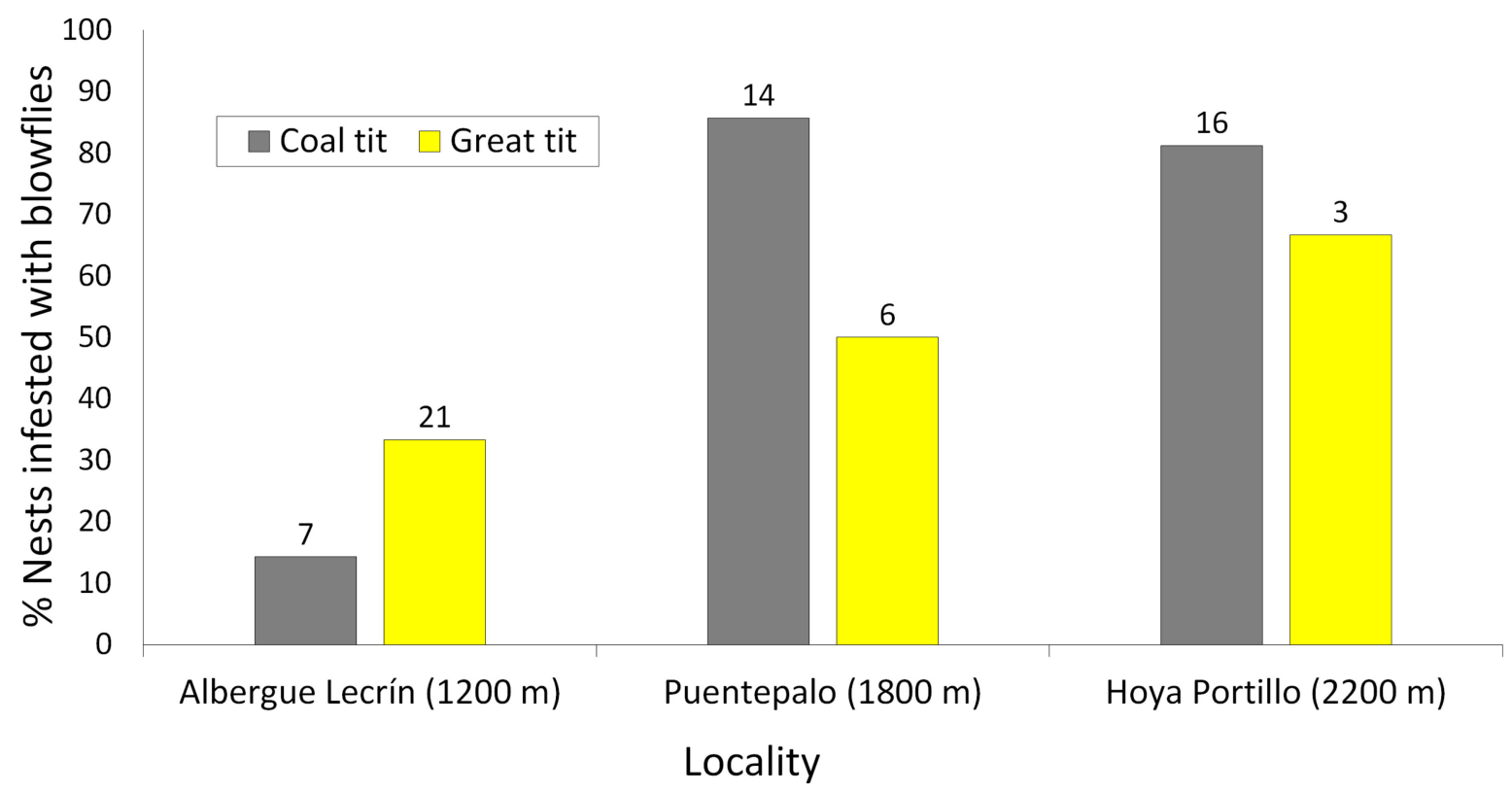

Figure 2. Percentage of coal tit (grey) and great tit (yellow) nests infested with blowfly larvae at each locality; the elevation is given in parenthesis. The numbers over bars indicate the sample size (number of nests inspected). 
Table 1. Results of a Generalised Linear Model with a binomial distribution linked to a logit function examining the effect of locality, species and its interaction (locality*species) on the prevalence of blowfly larvae in tit nests, with and without interaction. Degrees of freedom (DF), chi-squared, and $p$-values are indicated.

\begin{tabular}{cccc}
\hline & DF & $\chi^{2}$ & $p$ \\
\hline Locality & 2 & 11.53 & 0.003 \\
Species & 1 & 0.465 & 0.50 \\
Locality*Species & 2 & 3.69 & 0.16 \\
\hline
\end{tabular}

\section{Discussion}

The findings show that fewer coal tit and great tit nests were infested with Protocalliphora azurea larvae in the locality at a lower elevation (Albergue de Lecrín, $1200 \mathrm{~m}$ ), where only $14-33 \%$ of nests were parasitised. Meanwhile, at higher elevations, 1800 and $2200 \mathrm{~m}$, the prevalence was $\geq 50 \%$ of nests. The localities at 1800 and $2200 \mathrm{~m}$ are colder than that at $1200 \mathrm{~m}$ and it was predicted $P$. azurea would have a lower prevalence at higher elevations, mainly considering that the adult is a free-living fly that may be affected by adverse climates. However, although some studies have reported lower blowfly infestation rates in colder and wetter years $[13,64,65]$, humidity may have a greater influence than temperature in terms of regulating the fly's distribution, especially in Mediterranean habitats which tend to be low humidity environments. Another study into blue tits (Cyanistes caeruleus) carried out close to the locality at $1800 \mathrm{~m}$, found that $P$. azurea prevalence was higher in humid habitats than in dry forests [54]. In the Mediterranean environment inherent to Sierra Nevada, humidity increases with elevation due to lower temperatures (and therefore less evapotranspiration), snowmelt, and increased precipitation from clouds colliding with the high mountains. Experimental studies have also shown that blowfly larvae survival is lower in heated nest boxes [11,12]. Given that heating nest boxes affects nest humidity, it remains unclear whether larvae survival is affected by temperature or humidity [12]. In fact, nest humidity correlated positively with the number of $P$. azurea larvae in great tits breeding in Finland [66].

Alternatively, human perturbation, which decreases with elevation, might explain the lower prevalence of blowflies at Albergue de Lecrín. Indeed, while the pine forests in the localities at 1800 and $2200 \mathrm{~m}$ are relatively natural environments, the pine forest at Albergue de Lecrín is surrounded by agricultural land, mainly almond trees. Adult blowflies feed on flowers and fruits, so a degraded environment may reduce adult survival. This suggestion is supported by [67], who found a lower prevalence of $P$. azurea in nests sited in zones with degraded vegetation. Plus, biocides used by farmers might increase adult blowfly mortality. Indeed, contamination has been related to a reduced load of $P$. azurea $[66,67]$. Overall, they may be highly susceptible to environmental degradation and therefore represent good indicators of environment quality [68].

Elevational variation in blowfly prevalence could also be due to interactions with other species. The nest-dwelling haematophagous mite Dermanyssus gallinoides presents a negative correlation with blowfly prevalence [13]. However, no mite was found in the inspected nests, and only found fleas (Ceratophyllus gallinae) in Puentepalo, the locality at an intermediate elevation. Protocalliphora azurea pupae are parasitised by the parasitoid wasp Nasonia vitripennis, which may kill 21-69\% of pupae [54]. Therefore, parasitoid wasps may have a significant effect on P. azurea population dynamics, but it is unknown how the abundance of this parasitoid varies with elevation. Similarly, there is a lack of information concerning the natural history affecting P. azurea adults, so we do not know how predators, parasites or competitors vary with elevation during the adult phase.

Host defence could also depend on elevation, thus resulting in a variation in blowfly prevalence. Nestling immune defence has been associated with reduced blowfly load [21-23] and the strength of the immune response is known to increase with temperature $[27,28,69]$. 
Therefore, maybe tit nestlings manifest a weaker immune response against blowflies in colder environments. Nevertheless, this notion remains to be proven.

Parasite abundance frequently increases with host density [70]. However, host density, on the basis of nest-boxes occupancy, did not increase with elevation (28 nests in Albergue de Lecrín, 20 in Puentepalo, and 19 in Hoya del Portillo), so this explanation does not seem plausible.

Lastly, the two species presented similar parasite prevalence and intensities, suggesting they were affected by blowflies to the same extent (given that brood size was also similar between the two species). However, this should be nuanced, as great tits are almost twice as big as coal tits. Hence, if blowflies had the same mass in the two species, the coal tits were more severely parasitised than the great tits. Blowfly parasitism is known to vary among species in sympatry [71], although the reason for this variation is poorly known. Variations in parasitisation do not seem to be influenced by differences in nest composition [72-74], but between-species differences in antiparasitic strategies may account for variations in blowfly load [56]. Grab et al. [22] suggested that small host should invest more in resistance against blowfly larvae because they are more vulnerable as a consequence of their reduced size. They compared two species with different average weights, the eastern bluebird (Sialia sialis, 24-25 g) and tree swallow (Tachycineta bicolor, 19-20 g), and the number of blowflies per nestling was considerably lower in the smaller species. However, this was not the case in the present study, where the two host species harboured similar blowfly loads, despite a much greater difference in weight. The two host species considered in this study, moreover, are phylogenetically much closer and have similar ecology, including nests with very similar structure and composition. So, it remains unknown as to why coal and great tits harbour similar quantities of blowfly larvae despite of their difference in body mass, but it seems that blowflies attain higher survival in coal tit nests.

The correlative nature of this study prevents clear conclusions from being reached. Although the most plausible explanations for the pattern found have been discussed, other variables not considered could be the underlying cause of this pattern. An ideal comparison would require a larger number of locations along various elevation gradients and a larger sample size, which was limited by the low rate of nest-box occupancy. In fact, the low nest-box occupancy precluded to obtain data at elevations below $1200 \mathrm{~m}$, where the studied species also inhabit. Anyhow, the findings suggest that blowflies will not pose a threat to populations of birds inhabiting at higher elevations as a result of climate change and, in fact, blowfly populations at high elevations are which might be threatened by an increase in temperatures. Experimental studies and greater knowledge of the natural history of the dispersive phase of the blowfly (adults) would be necessary to understand the causes of geographic variation in the presence of this parasite.

In conclusion, the results of this study suggest that blowfly prevalence in coal and great tit nests increases with elevation in Mediterranean mountains, while intensity remains constant, at the least in the elevational range studied in Sierra Nevada. The reasons for this unexpected elevational pattern are yet to be clarified. The higher humidity of mid and high mountains in Mediterranean environments might favour blowflies at higher elevations; alternatively, a greater anthropogenic impact at lower elevations could have a negative effect on blowflies. Hence, the generalised assumption that parasite abundance decreases with elevation does not hold true for the present case and elevational parasite patterns probably depend on specific host-parasite systems and environmental conditions in the mountains.

Funding: The study was supported by the Spanish Ministerio de Economía y Competitividad (Plan Nacional projects CGL2014-55969-P and CGL2017-84938-P), financed with FEDER (European Union) funds. 
Institutional Review Board Statement: The study was conducted according to the guidelines of the Declaration of Helsinki, and approved by the Ethics Committee of the Andalusian Government (protocol code 03-06-15-259).

Data Availability Statement: The data presented in this study are openly available in Appendix A.

Acknowledgments: I thank José Luis Ros-Santaella, Eliana Pintus, Abelardo Requena-Blanco, Nuria Mora Encinas and, above all, Mar Comas for their support during fieldwork. Comments by Voelker and anonymous referees improved the manuscript.

Conflicts of Interest: The author declares no conflict of interest.

Ethics Statement: The research was conducted under the research permits of both Junta de Andalucía (authorization code 03-06-15-259 for animal research) and National Park of Sierra Nevada (authorization code WQVipIDPNi6QiPoQo8BnGA==).

\section{Appendix A}

Table A1. Raw data used in the study, indicating nest identification, locality, number of P. azurea pupae found in the nest and host species.

\begin{tabular}{|c|c|c|c|}
\hline Nest ID & Locality & P. azurea Pupae & Host Species \\
\hline A02 & Albergue de Lecrín & 0 & Parus major \\
\hline $\mathrm{A} 03$ & Albergue de Lecrín & 22 & Parus major \\
\hline A06 & Albergue de Lecrín & 0 & Parus major \\
\hline A07 & Albergue de Lecrín & 23 & Parus major \\
\hline A09 & Albergue de Lecrín & 0 & Periparus ater \\
\hline A09 & Albergue de Lecrín & 0 & Parus major \\
\hline A10 & Albergue de Lecrín & 0 & Periparus ater \\
\hline A12 & Albergue de Lecrín & 0 & Parus major \\
\hline A13 & Albergue de Lecrín & 0 & Parus major \\
\hline A15 & Albergue de Lecrín & 0 & Periparus ater \\
\hline A16 & Albergue de Lecrín & 17 & Parus major \\
\hline A18 & Albergue de Lecrín & 0 & Parus major \\
\hline A19 & Albergue de Lecrín & 0 & Parus major \\
\hline $\mathrm{A} 20$ & Albergue de Lecrín & 0 & Parus major \\
\hline $\mathrm{A} 27$ & Albergue de Lecrín & 0 & Parus major \\
\hline $\mathrm{A} 28$ & Albergue de Lecrín & 0 & Parus major \\
\hline A33 & Albergue de Lecrín & 0 & Periparus ater \\
\hline A38 & Albergue de Lecrín & 0 & Parus major \\
\hline A42 & Albergue de Lecrín & 0 & Parus major \\
\hline A43 & Albergue de Lecrín & 10 & Parus major \\
\hline A 45 & Albergue de Lecrín & 0 & Periparus ater \\
\hline A46 & Albergue de Lecrín & 2 & Parus major \\
\hline A 48 & Albergue de Lecrín & 0 & Periparus ater \\
\hline A51 & Albergue de Lecrín & 0 & Parus major \\
\hline A52 & Albergue de Lecrín & 2 & Periparus ater \\
\hline A54 & Albergue de Lecrín & 5 & Parus major \\
\hline A55 & Albergue de Lecrín & 28 & Parus major \\
\hline A60 & Albergue de Lecrín & 0 & Parus major \\
\hline H01 & Hoya del Portillo & 22 & Periparus ater \\
\hline $\mathrm{H} 03$ & Hoya del Portillo & 16 & Periparus ater \\
\hline $\mathrm{H} 04$ & Hoya del Portillo & 4 & Periparus ater \\
\hline H08 & Hoya del Portillo & 40 & Periparus ater \\
\hline $\mathrm{H} 12$ & Hoya del Portillo & 0 & Parus major \\
\hline $\mathrm{H} 13$ & Hoya del Portillo & 4 & Periparus ater \\
\hline H14 & Hoya del Portillo & 39 & Periparus ater \\
\hline H19 & Hoya del Portillo & 6 & Periparus ater \\
\hline $\mathrm{H} 26$ & Hoya del Portillo & 10 & Periparus ater \\
\hline H34 & Hoya del Portillo & 0 & Periparus ater \\
\hline $\mathrm{H} 36$ & Hoya del Portillo & 3 & Periparus ater \\
\hline
\end{tabular}


Table A1. Cont.

\begin{tabular}{|c|c|c|c|}
\hline Nest ID & Locality & P. azurea Pupae & Host Species \\
\hline H37 & Hoya del Portillo & 1 & Parus major \\
\hline H38 & Hoya del Portillo & 5 & Periparus ater \\
\hline $\mathrm{H} 43$ & Hoya del Portillo & 0 & Periparus ater \\
\hline $\mathrm{H} 46$ & Hoya del Portillo & 0 & Periparus ater \\
\hline $\mathrm{H} 50$ & Hoya del Portillo & 2 & Periparus ater \\
\hline H51 & Hoya del Portillo & 20 & Periparus ater \\
\hline H55 & Hoya del Portillo & 24 & Periparus ater \\
\hline $\mathrm{H} 60$ & Hoya del Portillo & 4 & Parus major \\
\hline P01 & Puentepalo & 10 & Periparus ater \\
\hline $\mathrm{P} 02$ & Puentepalo & 0 & Parus major \\
\hline P03 & Puentepalo & 0 & Parus major \\
\hline P04 & Puentepalo & 7 & Periparus ater \\
\hline P14 & Puentepalo & 1 & Periparus ater \\
\hline P21 & Puentepalo & 0 & Periparus ater \\
\hline P23 & Puentepalo & 2 & Periparus ater \\
\hline P25 & Puentepalo & 9 & Periparus ater \\
\hline P28 & Puentepalo & 0 & Parus major \\
\hline P29 & Puentepalo & 6 & Periparus ater \\
\hline P32 & Puentepalo & 9 & Parus major \\
\hline P33 & Puentepalo & 53 & Periparus ater \\
\hline P36 & Puentepalo & 18 & Periparus ater \\
\hline P43 & Puentepalo & 1 & Periparus ater \\
\hline P46 & Puentepalo & 6 & Periparus ater \\
\hline P53 & Puentepalo & 3 & Periparus ater \\
\hline P54 & Puentepalo & 0 & Periparus ater \\
\hline P57 & Puentepalo & 22 & Periparus ater \\
\hline P59 & Puentepalo & 37 & Parus major \\
\hline P60 & Puentepalo & 13 & Parus major \\
\hline
\end{tabular}

\section{References}

1. Schmid-Hempel, P. Evolutionary Parasitology: The Integrated Study of Infections, Immunology, Ecology, and Genetics; Oxford University Press: Oxford, UK, 2011.

2. Møller, A.P. Parasitism and the evolution of host life history. In Host-Parasite Evolution: General Principles and Avian Models; Clayton, D.H., Moore, J., Eds.; Oxford University Press: Oxford, UK, 1997; pp. 105-127.

3. Møller, A.P.; Arriero, E.; Lobato, E.; Merino, S. A meta-analysis of parasite virulence in nestling birds. Biol. Rev. 2009, 84, 567-588. [CrossRef]

4. Brown, C.R.; Brown, M.B. Ectoparasitism as a cost of coloniality in cliff swallows (Hirundo pyrrhonota). Ecology 1986, 67, 1206-1218. [CrossRef]

5. Fitze, P.S.; Clobert, J.; Richner, H. Long-term life-history consequences of ectoparasite-modulated growth and development. Ecology 2004, 85, 2018-2026. [CrossRef]

6. Thomas, D.W.; Shipley, B.; Blondel, J.; Perret, P.; Simon, A.; Lambrechts, M.M. Common paths link food abundance and ectoparasite loads to physiological performance and recruitment in nestling blue tits. Funct. Ecol. 2007, 21, 947-955. [CrossRef]

7. Richner, H.; Tripet, F. Ectoparasitism and the trade-off between current and future reproduction. Oikos 1999, 86, 535-538. [CrossRef]

8. Bennett, G.F.; Whitworth, T.L. Studies on the life history of some species of Protocalliphora (Diptera: Calliphoridae). Can. J. Zool. 1991, 69, 2048-2058. [CrossRef]

9. Veiga, J.; Moreno, E.; Benzal, J.; Valera, F. Off-host longevity of the winged dispersal stage of Carnus hemapterus (Insecta: Diptera) modulated by gender, body size and food provisioning. Parasitology 2019, 146, 241-245. [CrossRef]

10. Heeb, P.; Kölliker, M.; Richner, H. Bird ectoparasite interactions, nest humidity, and ectoparasite community structure. Ecology 2000, 81, 958-968.

11. Dawson, R.D.; Hillen, K.K.; Whitworth, T.L. Effects of experimental variation in temperature on larval densities of parasitic Protocalliphora (Diptera: Calliphoridae) in nests of tree swallows (Passeriformes: Hirundinidae). Environ. Entomol. 2005, 34, 563-568. [CrossRef]

12. Castaño-Vázquez, F.; Martínez, J.; Merino, S.; Lozano, M. Experimental manipulation of temperature reduce ectoparasites in nests of blue tits Cyanistes caeruleus. J. Avian Biol. 2018, 49, e01695. [CrossRef]

13. Merino, S.; Potti, J. Weather dependent effects of nest ectoparasites on their bird hosts. Ecography 1996, 19, 107-113. [CrossRef] 
14. Stephenson, S.; Hannon, S.; Proctor, H. The function of feathers in tree swallow nests: Insulation or ectoparasite barrier? Condor 2009, 111, 479-487. [CrossRef]

15. Clayton, D.H.; Koop, J.A.H.; Harbison, C.W.; Moyer, B.R.; Bush, S.E. How birds combat ectoparasites. Open Ornithol. J. 2010, 3, 41-71. [CrossRef]

16. Bush, S.E.; Clayton, D.H. Anti-parasite behaviour of birds. Philos. Trans. R. Soc. B 2018, 373, 20170196. [CrossRef] [PubMed]

17. Merino, S. Immunocompetence and parasitism in nestlings from wild populations. Open Ornithol. J. 2010, 3, 27-32. [CrossRef]

18. Owen, J.P.; Nelson, A.C.; Clayton, D.H. Ecological immunology of bird-ectoparasite systems. Trends Parasitol. 2010, 26, 530-539. [CrossRef]

19. Tschirren, B.; Bischoff, L.L.; Saladin, V.; Richner, H. Host condition and host immunity affect parasite fitness in a bird-ectoparasite system. Funct. Ecol. 2007, 21, 372-378. [CrossRef]

20. Bize, P.; Jeanneret, C.; Klopfenstein, A.; Roulin, A. What makes a host profitable? Parasites balance host nutritive resources against immunity. Am. Nat. 2008, 171, 107-118. [CrossRef]

21. DeSimone, J.G.; Clotfelter, E.D.; Black, E.C.; Knutie, S.A. Avoidance, tolerance, and resistance to ectoparasites in nestling and adult tree swallows. J. Avian Biol. 2018, 49, e01641. [CrossRef]

22. Grab, K.M.; Hiller, B.J.; Hurlbert, J.H.; Ingram, M.E.; Parker, A.B.; Pokutnaya, D.Y.; Knutie, S.A. Host tolerance and resistance to parasitic nest flies differs between two wild bird species. Ecol. Evol. 2019, 9, 12144-12155. [CrossRef] [PubMed]

23. Knutie, S.A. Food supplementation affects gut microbiota and immunological resistance to parasites in a wild bird species. $J$. Appl. Ecol. 2020, 57, 536-547. [CrossRef]

24. Møller, A.P.; Martín-Vivaldi, M.; Merino, S.; Soler, J.J. Density-dependent and geographical variation in bird immune response. Oikos 2006, 115, 463-474. [CrossRef]

25. Saino, N.; Calza, S.; Møller, A.P. Immunocompetence of nestling barn swallows in relation to brood size and parental effort. J. Anim. Ecol. 1997, 66, 827-836. [CrossRef]

26. Hoi-Leitner, M.; Romero-Pujante, M.; Hoi, H.; Pavlova, A. Food availability and immune capacity in serin (Serinus serinus) nestlings. Behav. Ecol. Sociobiol. 2001, 49, 333-339. [CrossRef]

27. Ardia, D.R. Cross-fostering reveals an effect of spleen size and nest temperatures on immune responses in nestling European starlings. Oecologia 2005, 145, 327-334. [CrossRef]

28. Garvin, J.C.; Abroe, B.; Pedersen, M.C.; Dunn, P.O.; Whittingham, L.A. Immune response of nestling warblers varies with extra-pair paternity and temperature. Mol. Ecol. 2006, 15, 3833-3840. [CrossRef]

29. Merino, S.; Møller, A.P. Host-parasite interactions and climate change. In Effects of Climate Change on Birds; Møller, A.P., Fiedler, W., Berthold, P., Eds.; Oxford University Press: Oxford, UK, 2010; pp. 213-226.

30. Møller, A.P.; Merino, S.; Soler, J.J.; Antonov, A.; Badás, E.P.; Calero-Torralbo, M.A.; de Lope, F.; Eeva, T.; Figuerola, J.; FlenstedJensen, E.; et al. Assessing the effects of climate on host-parasite interactions: A comparative study of European birds and their parasites. PLoS ONE 2013, 8, e82886. [CrossRef]

31. Pounds, J.A.; Bustamante, M.R.; Coloma, L.A.; Consuegra, J.A.; Fogden, M.P.L.; Foster, P.N.; La Marca, E.; Masters, K.L.; Merino-Viteri, A.; Puschendorf, R.; et al. Widespread amphibian extinctions from epidemic disease driven by global warming. Nature 2006, 439, 161-167. [CrossRef]

32. Badyaev, A.V. Altitudinal variation in sexual dimorphism: A new pattern and alternative hypotheses. Behav. Ecol. 1997, 8, 675-690. [CrossRef]

33. Baur, A.; Baur, B. Interpopulation variation in the prevalence and intensity of parasitic mite infection in the land snail Arianta arbustorum. Invertebr. Biol. 2005, 124, 194-201. [CrossRef]

34. Meléndez, L.; Laiolo, P.; Mironov, S.; García, M.; Magaña, O.; Jovani, R. Climate-driven variation in the intensity of a host-symbiont animal interaction along a broad elevation gradient. PLoS ONE 2014, 9, e101942. [CrossRef]

35. Álvarez-Ruiz, L.; Megía-Palma, R.; Reguera, S.; Ruiz, S.; Zamora-Camacho, F.J.; Figuerola, J.; Moreno-Rueda, G. Opposed elevational variation in prevalence and intensity of endoparasites and their vectors in a lizard. Curr. Zool. 2018, 64, 197-204. [CrossRef] [PubMed]

36. Carbayo, J.; Martín, J.; Civantos, E. Habitat type influences parasite load in Algerian Psammodromus algirus. Can. J. Zool. 2019, 97, 172-180. [CrossRef]

37. Llanos-Garrido, A.; Díaz, J.A.; Pérez-Rodríguez, A.; Arriero, E. Variation in male ornaments in two lizard populations with contrasting parasite loads. J. Zool. 2017, 303, 218-225. [CrossRef]

38. Seddon, R.J.; Hews, D.K. Correlates of melanization in multiple high- and low-elevation populations of the lizard, Sceloporus occidentalis: Behavior, hormones, and parasites. J. Exp. Zool. Part A 2017, 327, 481-492. [CrossRef]

39. Comas, M. Body condition, sex and elevation in relation to mite parasitism in a high mountain gecko. J. Zool. 2020, 310, 298-305. [CrossRef]

40. Wiedenfeld, D.A.; Jiménez U., G.A.; Fessl, B.; Kleindorfer, S.; Valarezo, J.C. Distribution of the introduced parasitic fly Philornis downsi (Diptera, Muscidae) in the Galapagos Islands. Pac. Conserv. Biol. 2007, 13, 14. [CrossRef]

41. O'Connor, J.A.; Dudaniec, R.Y.; Kleindorfer, S. Parasite infestation and predation in Darwin's small ground finch: Contrasting two elevational habitats between islands. J. Trop. Ecol. 2010, 26, 285-292. [CrossRef]

42. Young, B.E. Effects of the parasitic botfly Philornis carinatus on nestling house wrens, Troglodytes aedon, in Costa Rica. Oecologia 1993, 93, 256-262. [CrossRef] 
43. Hurtrez-Boussès, S.; Blondel, J.; Perret, P.; Renaud, F. Relationship between intensity of blowfly infestation and reproductive success in a Corsican population of Blue Tits. J. Avian Biol. 1997, 28, 267-270. [CrossRef]

44. Hurtrez-Boussès, S.; Perret, P.; Renaud, F.; Blondel, J. High blowfly parasitic loads affect breeding success in a Mediterranean population of blue tits. Oecologia 1997, 112, 514-517. [CrossRef] [PubMed]

45. Merino, S.; Potti, J. Growth, nutrition, and blow fly parasitism in nestling Pied Flycatchers. Can. J. Zool. 1998, 76, 936-941. [CrossRef]

46. Bańbura, J.; Perret, P.; Blondel, J.; Thomas, D.W.; Cartan-Son, M.; Lambrechts, M.M. Effects of Protocalliphora parasites on nestling food composition in Corsican Blue Tits Parus caeruleus: Consequences for nestling performance. Acta Ornithol. 2004, 39, 93-103. [CrossRef]

47. Puchala, P. Detrimental effects of larval blow flies (Protocalliphora azurea) on nestlings and breeding success of Tree Sparrows (Passer montanus). Can. J. Zool. 2004, 82, 1285-1290. [CrossRef]

48. Simon, A.; Thomas, D.; Blondel, J.; Perret, P.; Lambrechts, M.M. Physiological ecology of Mediterranean blue tits (Parus caeruleus L.): Effects of ectoparasites (Protocalliphora spp.) and food abundance on metabolic capacity of nestlings. Physiol. Biochem. Zool. 2004, 77, 492-501. [CrossRef]

49. Arriero, E.; Moreno, J.; Merino, S.; Martínez, J. Habitat effects on physiological stress response in nestling blue tits are mediated through parasitism. Physiol. Biochem. Zool. 2008, 81, 195-203. [CrossRef]

50. Merino, S.; Potti, J. Mites and blowflies decrease growth and survival in nestling pied flycatchers. Oikos 1995, 73, 95-103. [CrossRef]

51. Bouslama, Z.; Chabi, Y.; Lambrechts, M. Chicks resist high parasite intensities in an Algerian population of blue tits. Écoscience 2001, 8, 320-324. [CrossRef]

52. Potti, J. Blowfly infestation at the nestling stage affects egg size in the Pied Flycatcher Ficedula hypoleuca. Acta Ornithol. 2008, 43, 76-82. [CrossRef]

53. Eeva, T.; Andersson, T.; Berglund, Å.M.M.; Brommer, J.E.; Hyvönen, R.; Klemola, T.; Laaksonen, T.; Loukola, O.; Morosinotto, C.; Rainio, K.; et al. Species and abundance of ectoparasitic flies (Diptera) in pied flycatcher nests in Fennoscandia. Parasites Vectors 2015, 8, 648. [CrossRef]

54. Garrido-Bautista, J.; Moreno-Rueda, G.; Baz, A.; Canal, D.; Camacho, C.; Cifrián, B.; Nieves-Aldrey, J.L.; Carles-Tolrá, M.; Potti, J. Variation in parasitoidism of Protocalliphora azurea (Diptera: Calliphoridae) by Nasonia vitripennis (Hymenoptera: Pteromalidae) in Spain. Parasitol. Res. 2020, 119, 559-566. [CrossRef] [PubMed]

55. Gold, C.S.; Dahlsten, D.L. Prevalence, habitat selection, and biology of Protocalliphora (Diptera: Calliphoridae) found in nests of mountain and chestnut-backed chickadees in California. Hilgardia 1989, 57, 1-19. [CrossRef]

56. Hori, K.; Iwasa, M.; Ogawa, R. Biology of two species of the Protocalliphora (Diptera: Calliphoridae) in Tokachi, Hokkaido, Japan: Feeding behaviour of larvae, larval and pupal duration, voltinism and host specificity. Appl. Entomol. Zool. 1990, 25, 475-482. [CrossRef]

57. Polo, V. Carbonero Garrapinos-Periparus ater (Linnaeus, 1758). In Enciclopedia Virtual de los Vertebrados Españoles; Salvador, A., Morales, M.B., Eds.; Museo Nacional de Ciencias Naturales: Madrid, Spain, $2016 . \quad$ Available online: http:/ / www.vertebradosibericos.org (accessed on 13 May 2021).

58. Gosler, A. The Great Tit; Hamlyn: London, UK, 1993.

59. Atiénzar, F.; Álvarez, E.; Barba, E. Carbonero común-Parus major (Linnaeus, 1758). In Enciclopedia Virtual de los Vertebrados Españoles; Salvador, A., Morales, M.B., Eds.; Museo Nacional de Ciencias Naturales: Madrid, Spain, 2016. Available online: http: / / www.vertebradosibericos.org (accessed on 21 June 2021).

60. Baucells Colomer, J.; Camprodon i Subirachs, J.; Cerdeira i Ribot, J.; Vila Perdiguero, P. Guía de las Cajas Nido y Comederos Para Aves y Otros Vertebrados; Lynx Edicions: Barcelona, Spain, 2003.

61. Moreno-Rueda, G. Selección de cajas-nido por aves insectívoras en Sierra Nevada. Zool. Baet. 2003, 13, $131-138$.

62. Rózsa, L.; Reiczigel, J.; Majoros, G. Quantifying parasites in samples of hosts. J. Parasitol. 2000, 86, 228-232. [CrossRef]

63. Zuur, A.F.; Ieno, E.N.; Elphick, C.S. A protocol for data exploration to avoid common statistical problems. Methods Ecol. Evol. 2010, 1, 3-14. [CrossRef]

64. Johnson, L.S.; Eastman, M.D.; Kermott, L.H. Effect of ectoparasitism by larvae of the blow fly Protocalliphora parorum (Diptera: Calliphoridae) on nestling House Wrens, Troglodytes aedon. Can. J. Zool. 1991, 69, 1441-1446. [CrossRef]

65. Musgrave, K.; Bartlow, A.W.; Fair, J.M. Long-term variation in environmental conditions influences host-parasite fitness. Ecol. Evol. 2019, 9, 7688-7703. [CrossRef]

66. Eeva, T.; Lehikoinen, E.; Nurmi, J. Effects of ectoparasites on breeding success of great tits (Parus major) and pied flycatchers (Ficedula hypoleuca) in an air pollution gradient. Can. J. Zool. 1994, 72, 624-635. [CrossRef]

67. Eeva, T.; Klemola, T. Variation in prevalence and intensity of two avian ectoparasites in a polluted area. Parasitology 2013, 140, 1384-1393. [CrossRef]

68. Lafferty, K.D. Environmental parasitology: What can parasites tell us about human impacts on the environment? Parasitol. Today 1997, 13, 251-255. [CrossRef]

69. Butler, M.W.; Garvin, J.C.; Wheelwright, N.T.; Freeman-Gallant, C.R. Ambient temperature, but not paternity, is associated with immune response in savannah sparrows (Passerculus sandwichensis). Auk 2009, 126, 536-542. [CrossRef] 
70. Arneberg, P.; Skorping, A.; Grenfell, B.; Read, A.F. Host densities as determinants of abundance in parasite communities. Proc. R. Soc. Lond. Ser. B 1998, 265, 1283-1289. [CrossRef]

71. Bennett, G.F.; Whitworth, T.L. Host, nest, and ecological relationship of species of Protocalliphora (Diptera: Calliphoridae). Can. J. Zool. 1992, 70, 51-61. [CrossRef]

72. Cantarero, A.; López-Arrabé, J.; Rodríguez-García, V.; González-Braojos, S.; Ruiz-De-Castañeda, R.; Redondo, A.J.; Moreno, J. Factors affecting the presence and abundance of generalist ectoparasites in nests of three sympatric hole-nesting bird species. Acta Ornithol. 2013, 48, 39-54. [CrossRef]

73. Moreno, J.; Merino, S.; Lobato, E.; Ruiz-De-Castañeda, R.; Martínez-de la Puente, J.; del Cerro, S.; Rivero-de Aguilar, J. Nestdwelling ectoparasites of two sympatric hole-nesting passerines in relation to nest composition: An experimental study. Écoscience 2009, 16, 418-427. [CrossRef]

74. Remeš, V.; Krist, M. Nest design and the abundance of parasitic Protocalliphora blow flies in two hole-nesting passerines. Écoscience 2005, 12, 549-553. [CrossRef] 